\title{
Friction and Wear Behavior of Fiber Reinforced Polymer-Matrix Composites Containing Ulexite and Pinus Brutia Cone Dust
}

\author{
Banu Sugözü \\ Mersin University, Engineering Faculty, Mechanical Engineering Department, Mersin, Turkey
}

ORCID: B. Sugözü(0000-0002-7798-2677)

\begin{abstract}
In this study, the usability of ulexite and pinus brutia cone dust (PBCD) in friction composites were investigated experimentally. Polymer-matrix composite (PMC) samples were manufactured by powder metallurgy method. Produced samples with the same contents were compared with those of heat-treated. A special design friction tester was used to determine friction properties such as wear rate and friction coefficient. The results showed that ulexite and PBCD can be used as filler material in friction composites. The results also indicated that heat treatment improved the properties of the samples.
\end{abstract}

Key Words: brake friction composite, wear, ulexite, pinus brutia cone dust, tribology

\section{INTRODUCTION}

Brake linings are important element of brake systems. Brake linings are composite materials formed by the combination of many materials. Brake linings are also referred to as brake composites or friction composites. Phenolic resin is generally used as a binder in polymer matrix friction composites. A variety of fibers can be used as reinforcing elements. There are several studies occurred by using different fibers in the literature [1-13]. Various additional materials are required for friction composites to exhibit high friction performance. These materials are called friction modifiers and are classified as abrasive and non-abrasive. Non-abrasive materials contain metallic chips and solid lubricants. According to the studies, if a material improves the friction properties of the composite, it can be used as friction modifier. In the literature, there are studies that have been done by adding many different materials to friction composites [14-17].

Fewer studies have been carried out related to boron minerals in friction composites [18-22]. It is also difficult to find study related to friction composites with pine cone dust. In earlier study [23] while investigated usage of ulexite in the friction composites, it was concluded that ulexite improved the wear and friction performance of composites. The studies related to pine cone dust in friction composites also indicated that pine cone dust was an ideal material as friction modifier for friction composites.
In this study, the friction composites with different combinations of both ulexite and PBCD were designed and produced by powder metallurgy including powder weighing, mixing, pre-forming and hot pressing, respectively. The samples produced were compared with those whose contents were the same but applied to heat treatment. Wear and friction properties were determined using a special design friction tester.

\section{MATERIAL AND METHODS}

The composite samples were manufactured by adding phenolic resin as binder, steel wool as fiber, $\mathrm{Al}_{2} \mathrm{O}_{3}$ as abrasive, graphite as solid lubricant, brass powder and copper powder as metallic chips and barite as space filler. Raw materials used in this study are listed in Table 1. The letters $U$ and $\mathrm{P}$ represent ulexite and $\mathrm{PBCD}$, and the number represents the amount percentage in the composite. The heat-treated samples are coded with letter $\mathrm{H}$. In five composites containing seven components with a fixed amount (76\%), the amount of ulexite was balanced with PBCD.

A conventional dry mixing method was employed to produce friction composites. The general stages of production are shown in Fig. 1.

Firstly, the powder materials were passed through the sieves to be of the same size and weighed by precision scales and mixed at $150 \mathrm{rpm}$ using a mixer for $10 \mathrm{~min}$. The mixture 
Table 1. Raw materials used in this study (wt.\%)

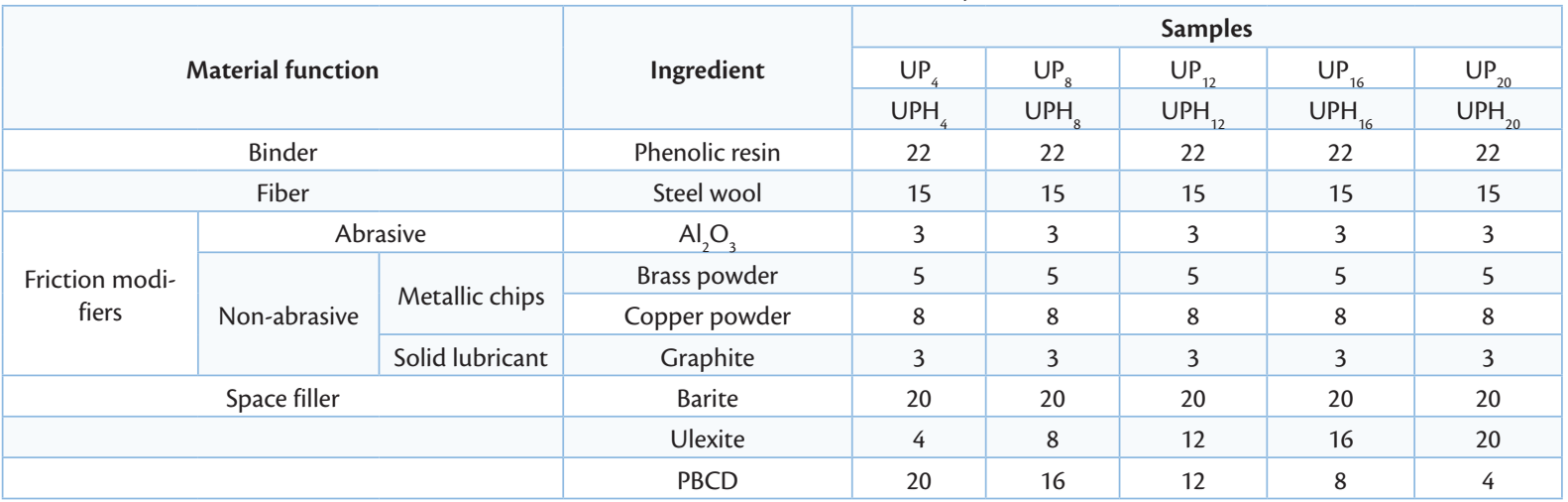

was subjected to a pressure of $8 \mathrm{MPa}$ for 2 minutes at room temperature in the pre-forming process. The ultimate sample was obtained by applying a pressure of $14 \mathrm{MPa}$ at $180{ }^{\circ} \mathrm{C}$ for 10 minutes in the hotpressing process. $\mathrm{H}$-coded samples $\left(\mathrm{UPH}_{4}, \mathrm{UPH}_{8}, \mathrm{UPH}_{12}, \mathrm{UPH}_{16}, \mathrm{UPH}_{20}\right)$ were sintered at $180^{\circ} \mathrm{C}$ for 4 hours in a heat-treatment oven. The devices used for sample production are shown in Fig. 2.

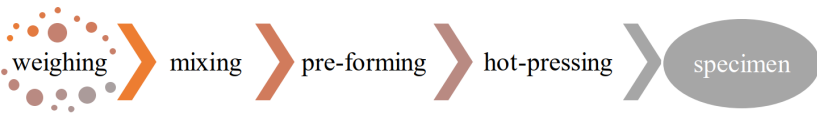

Fig. 1. The general stages of production

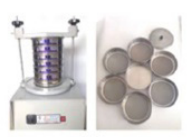

(a)

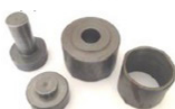

(e)

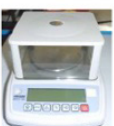

(b)

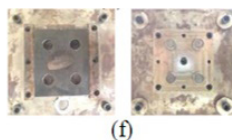

(f)

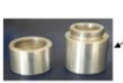

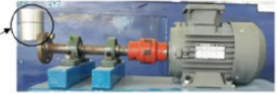

(d)

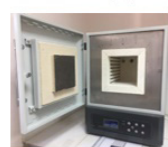

(g)
Fig.2. The materials used the production of samples (a) the sieve-shaker and sieves (b) the precision scales (c) the powder chamber (d) the powder mixing device (e) the cold press mold ( $f$ ) the hot press mold $(g)$ the heat treatment oven

The friction composites were subjected to various physical tests. Hardness of the specimens was measured by using Brinell hardness tester (average of five values on various spots of the friction surface). Density of the samples was calculated based on Archimedes principle. To evaluate fiction end wear properties of friction composites, tests were performed on a special design brake tester according to TSE 555 [24]. The schematic view of the brake tester is shown in Fig. 3.

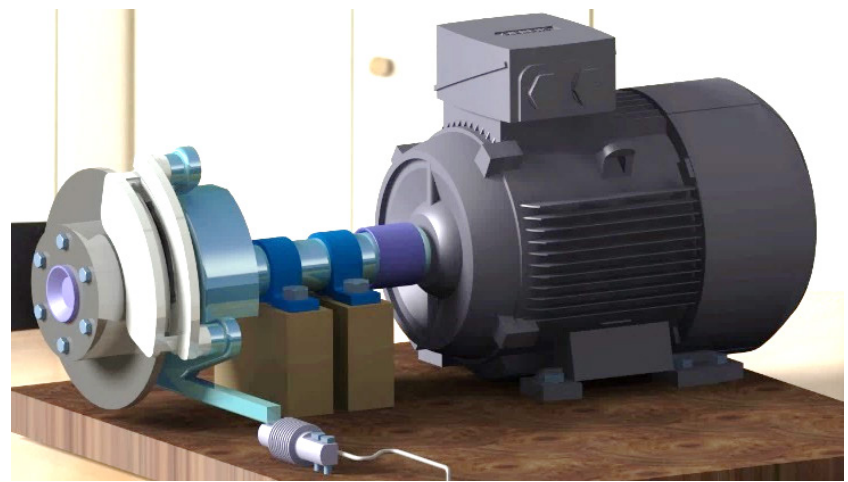

Fig. 3. The brake test device
The tester device is fully computer controllable and comprises of data acquisition software. As a counterpart, we used the disk made of grey cast iron with a $280 \mathrm{~mm}$ diameter and a hardness of $116 \mathrm{HB}$. The test samples are with usual dimensions of $25.4 \mathrm{~mm}$ in diameter and $6 \mathrm{~mm}$ in thickness. Before the friction test, the samples were burnished to obtain at least $\% 95$ contact of pre-test status. Friction tests were carried out under temperature group A (temperature to $350^{\circ} \mathrm{C}$ and $1050 \mathrm{kPa}$ pressure) as specified in TS 9076 [25]. For the test conditions, the speed was determined as $6 \mathrm{~m} / \mathrm{s}$, and the friction duration was 10 minutes. The surface temperature of the samples was measured using a non-contacting infrared thermometer. Before and after testing, samples weighed using a scale with $10^{-4} \mathrm{~g}$ precision and thus wear losses were determined. The wear rate of the friction samples was obtained by measuring the thickness change during the test procedure. All tests were repeated five times and average values are presented.

\section{RESULTS AND DISCUSSION}

It is desirable that the wear rate is low and the friction coefficient is high in friction composites used for brake. Also, the friction stability of the composites must be high for effective braking performance. The friction coefficient of the samples was recorded during the brake test to determine the properties of the samples such as friction and wear. Fig. 4 and Fig. 5 show variation of friction coefficient of samples depending on friction duration. An incipient increase in the friction coefficient was observed due to the run-in process [26]. When the figures were examined, a fluctuating progress was observed in the friction coefficients of all samples. However, samples coded UP4 and UP20 showed a more unstable structure. In the following stages of the test, the friction coefficient was adversely affected as the temperature caused by friction increased. When the graphs are examined, it is seen that the heat-treated samples are less stable. However, heat treated samples had higher average friction coefficient.

Increased heat due to friction between the disc and the friction surface affects mechanical properties. Because the material changes more space under the same force and thus increases the effective contact area [27]. The time-dependent variation of the temperature caused by the friction between the composite and the disc is shown in Fig. 6 and 
Fig. 7. The thermal decomposition of the ingredient brings about overabundant fade and wear. Fade phenomena occurred stopping power is not sufficient, which is based on mechanical fade, brake fluid boiling and thermal decomposition of friction materials [26].
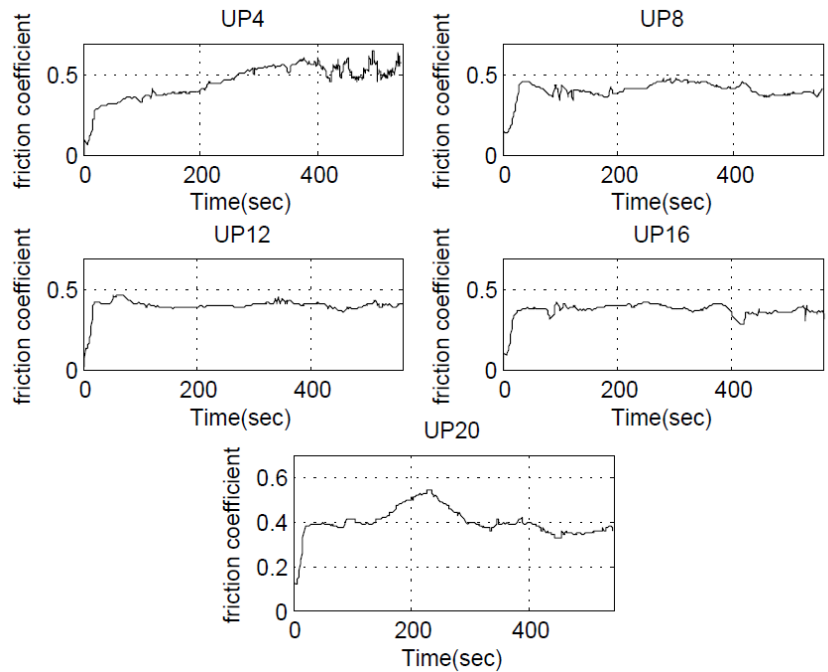

Fig. 4. Variation of friction coefficient of samples coded UP depending on friction duration
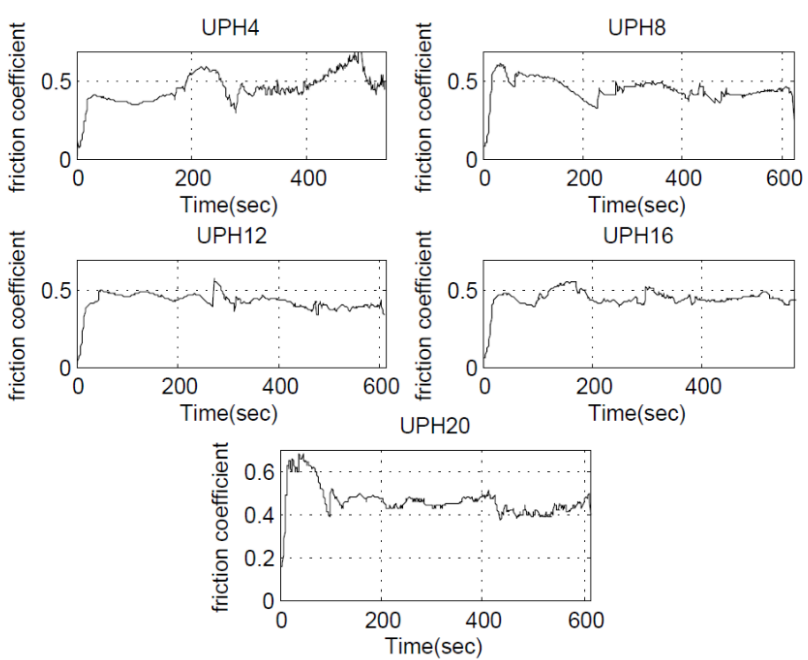

Fig. 5. Variation of friction coefficient of heat-treated samples depending on friction duration

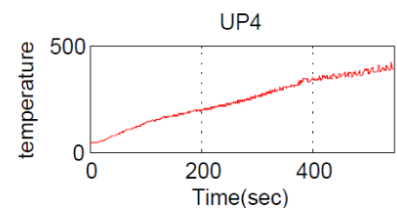

UP12
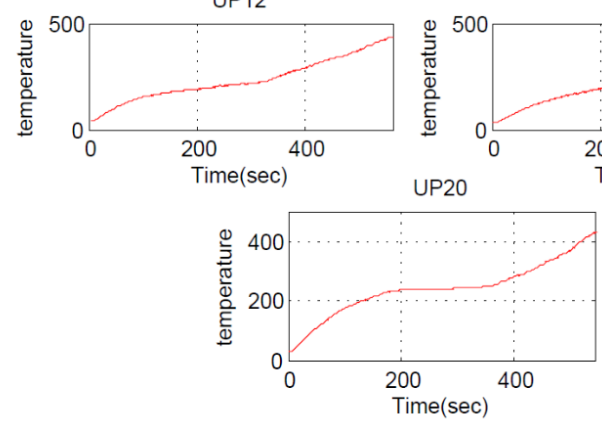

Fig. 6. Variation of surface temperature of samples coded UP depending on friction duration
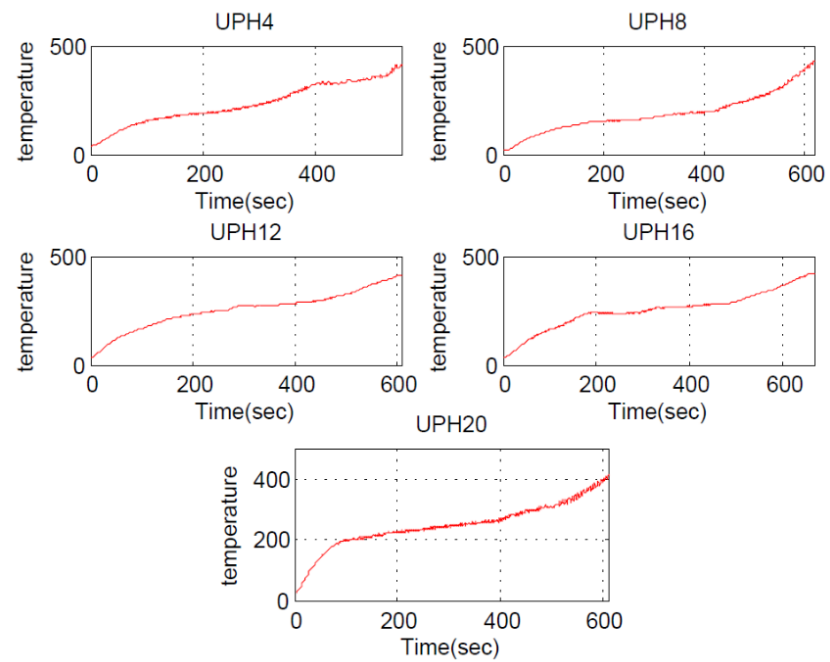

Fig. 7. Variation of surface temperature of heat-treated samples depending on friction duration

Friction stability is important parameter for friction composites. Because drivers expect the same friction force to perform the same performance under unexpected braking conditions. The materials forming the brake friction composites affect the friction stability. Therefore, proprietary friction additives are used in commercial products [28]. The percent friction stability of the samples is shown in Fig. 8.

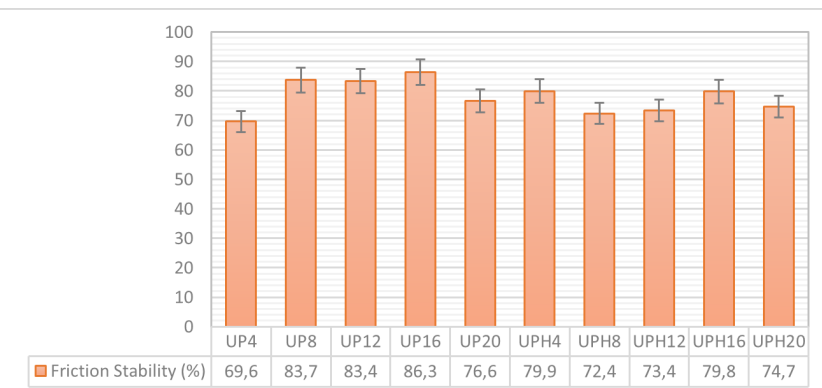

Fig. 8. The friction stability of the samples

The friction characteristics of the samples are shown in Fig. 9. When the friction characteristics of the samples are examined, the average friction coefficient value of the sample with UPH4 code containing 20\% PBCD and 4\% ulexite is higher than the others. In addition, heat treatment application increased friction coefficient of samples. When the specific wear rate values are considered, it is concluded that there is not a trend that is proportional to the amount of PBCD and ulexite.

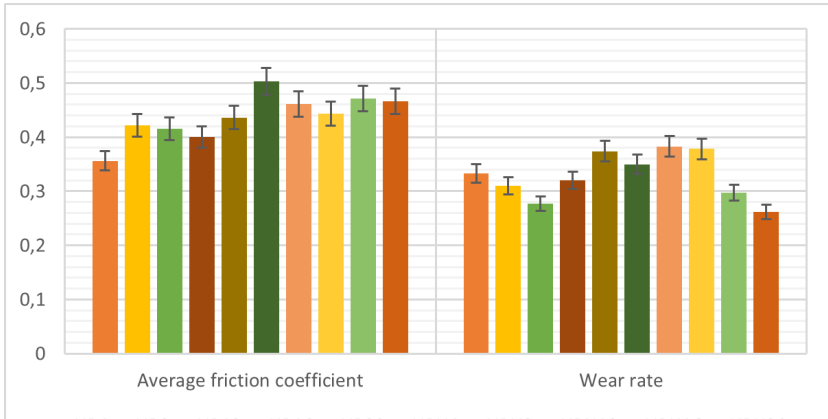

Fig. 9. The frictional properties of the samples 
Life of the friction composite depends on wear resistance, the ingredients and manufacturing parameters. The properties of the samples such as wear rate, hardness, density and average friction coefficient are given in Table 2.

Table 2. The properties of friction composites used in this study

\begin{tabular}{|c|c|c|c|c|}
\hline $\begin{array}{c}\text { Sample } \\
\text { Code }\end{array}$ & $\begin{array}{c}\text { Density }(\mathrm{g} / \\
\left.\mathrm{cm}^{3}\right)\end{array}$ & $\begin{array}{c}\text { Brinell hard- } \\
\text { ness }(\mathrm{HB})\end{array}$ & $\begin{array}{c}\text { Wear rate } \\
\times 10^{-6}\left(\mathrm{~g} / \mathrm{mm}^{2}\right)\end{array}$ & $\begin{array}{c}\text { Average fricti- } \\
\text { on coefficient }\end{array}$ \\
\hline $\mathrm{UP}_{4}$ & 2.263 & 32.3 & 0.333 & 0.356 \\
\hline $\mathrm{UP}_{8}$ & 2.200 & 29.1 & 0.310 & 0.422 \\
\hline $\mathrm{UP}_{12}$ & 2.203 & 31.8 & 0.277 & 0.415 \\
\hline $\mathrm{UP}_{16}$ & 2.523 & 34.3 & 0.320 & 0.400 \\
\hline $\mathrm{UP}_{20}$ & 2.131 & 27.5 & 0.374 & 0.436 \\
\hline $\mathrm{UPH}_{4}$ & 2.255 & 33.3 & 0.350 & 0.503 \\
\hline $\mathrm{UPH}_{8}$ & 2.197 & 30.1 & 0.383 & 0.461 \\
\hline $\mathrm{UPH}_{12}$ & 2.242 & 30.9 & 0.378 & 0.443 \\
\hline $\mathrm{UPH}_{16}$ & 2.122 & 29.6 & 0.297 & 0.471 \\
\hline $\mathrm{UPH}_{20}$ & 2.099 & 28.3 & 0.262 & 0.466 \\
\hline
\end{tabular}

Samples of $\mathrm{UPH}_{4}$ and $\mathrm{UPH}_{16}$ have good friction properties. Especially, $\mathrm{UPH}_{4}$ shows the maximum friction coefficient among the formulations. As shown in Table 2, applying heat-treatment improved both physical properties and friction properties of samples.

\section{CONCLUSION}

In this study, friction composites containing ulexite and PBCD were designed and produced. Physical properties and friction properties of the samples were examined. According to the test results, all samples are compatible with the literature, applicable in industry and comply with TS 555 standard. There is no direct correlation between the physical properties and friction characteristics of the brake friction composites. Ulexite and PBCD can be used as friction modifier and filler material in brake friction composites. Heat treatment has significantly improved both the physical and friction properties of the composites.

\section{REFERENCES}

[1] Öztürk, B., Arslan, F., Öztürk, S., (2013). Effects of Different Kinds of Fibers on Mechanical and Tribological Properties of Brake Friction Materials. Tribology Transactions 56(4): 536-45, Doi: 10.1080/10402004.2013.767399.

[2] Singh, T., Patnaik, A., (2015). Performance assessment of lapinus-aramid based brake pad hybrid phenolic composites in friction braking. Archives of Civil and Mechanical Engineering 15(1): 151-61, Doi: 10.1016/j.acme.2014.01.009.

[3] Nirmal, U., Hashim, J., Megat Ahmad, M.M.H., (2015). A review on tribological performance of natural fibre polymeric composites. Tribology International: 77-104, Doi: 10.1016/j.triboint.2014.11.003.

[4] Ikpambese, K.K., Gundu, D.T., Tuleun, L.T., (2016). Evaluation of palm kernel fibers (PKFs) for production of asbestos-free automotive brake pads. Journal of King Saud University - Engineering Sciences 28(1): 110-8, Doi: 10.1016/j.jksues.2014.02.001.

[5] Xin, X., Xu, C.G., Qing, L.F., (2007). Friction properties of sisal fibre reinforced resin brake composites. Wear 262(5-6): 736-41, Doi: 10.1016/j.wear.2006.08.010.

[6] Bijwe, J., Kumar, M., (2007). Optimization of steel wool contents in non-asbestos organic ( NAO ) friction composites for best combi- nation of thermal conductivity and tribo-performance 263: 1243-8, Doi: 10.1016/j.wear.2007.01.125.

[7] Satapathy, B.K., Bijwe, J., (2004). Performance of friction materials based on variation in nature of organic fibres Part I. Fade and recovery behaviour. Wear 257(5-6): 573-84, Doi: 10.1016/j.wear.2004.03.003.

[8] Zhang, X., Li, K.-Z., Li, H.-J., Fu, Y.-W., Fei, J., (2014). Tribological and mechanical properties of glass fiber reinforced paper-based composite friction material. Tribology International 69: 156-67, Doi: 10.1016/j.triboint.2013.08.003.

[9] Jang, H., Ko, K., Kim, S.., Basch, R.., Fash, J.., (2004). The effect of metal fibers on the friction performance of automotive brake friction materials. Wear 256(3-4): 406-14, Doi: 10.1016/S0043-1648(03)004459 .

[10] Qu, X., Zhang, L., Ding, H., Liu, G., (2004). The Effect of Steel Fiber Orientation on Frictional Properties of Asbestos-Free Friction Materials. Polymer Composites 25(1): 94-101.

[11] Aranganathan, N., Mahale, V., Bijwe, J., (2016). Effects of aramid fiber concentration on the friction and wear characteristics of non-asbestos organic friction composites using standardized braking tests. Wear 354-355: 69-77, Doi: 10.1016/j.wear.2016.03.002.

[12] Fei, J., Li, H.-J., Fu, Y.-W., Qi, L.-H., Zhang, Y.-L., (2010). Effect of phenolic resin content on performance of carbon fiber reinforced paper-based friction material. Wear 269(7-8): 534-40, Doi: 10.1016/J. WEAR.2010.05.008.

[13] Satapathy, B.K., Patnaik, A., Dadkar, N., Kolluri, D.K., Tomar, B.S., (2011). Influence of vermiculite on performance of flyash-based fibre-reinforced hybrid composites as friction materials. Materials and Design 32(8-9): 4354-61, Doi: 10.1016/j.matdes.2011.04.004.

[14] Lenin Singaravelu, D., Vijay, R., Rahul, M., (2015). Influence of Crab Shell on Tribological Characterization of Eco-Friendly Products Based Non Asbestos Brake Friction Materials. SAE Brake Colloquium \& Exhibition - 33rd Annual,.

[15] Antonyraj, J.I., Vijay, R., Singaravelu, L.D., (2019). Industrial Lubrication and Tribology Influence of WS 2 /SnS 2 on the tribological performance of copper-free brake pads Article information. Industrial Lubrication and Tribology, Doi: 10.1108/ILT-06-2018-0249.

[16] Öztürk, B., Mutlu, T., (2016). Effects of Zinc Borate and Fly Ash on the Mechanical and Tribological Characteristics of Brake Friction Materials. Tribology Transactions 59(4): 622-31, Doi: 10.1080/10402004.2015.1096984.

[17] Jeganmohan, S., Christy, T.V., Darius Gnanaraj, S., Sugozu, B., (2019). Influence of calcium sulfate whiskers on the tribological characteristics of automotive brake friction materials. Engineering Science and Technology, an International Journal, Doi: 10.1016/J.JESTCH.2019.06.007.

[18] Akıncıoğlu, G., Öktem, H., Uygur, l., Akıncıoğlu, S., (2018). Determination of Friction-Wear Performance and Properties of Eco-Friendly Brake Pads Reinforced with Hazelnut Shell and Boron Dusts. Arabian Journal for Science and Engineering 43: 4727-37, Doi: 10.1007/ s13369-018-3067-8.

[19] Uygunoğlu, T., Brostow, W., Gunes, I., Uygunoğlu, T., Brostow, W., Gunes, l., (2015). Wear and friction of composites of an epoxy with boron containing wastes. Polímeros 25(3): 271-6, Doi: 10.1590/01041428.1780 .

[20] Wannik, W.B., Ayob, A.F., Syahrullail, S., Masjuki, H.H., Ahmad, M.F., (2012). The effect of boron friction modifier on the performance of brake pads. International Journal of Mechanical and Materials Engineering 7(1): $31-5$ 
[21] Mutlu, l., Oner, C., Findik, F., (2007). Boric acid effect in phenolic composites on tribological properties in brake linings 28(2): 480-7.

[22] Sugozu, I., Mutlu, I., Sugozu, K.B., (2016). The effect of colemanite on the friction performance of automotive brake friction materials. Industrial Lubrication and Tribology 68(1): 92-8, Doi: 10.1108/ILT04-2015-0044.

[23] Sugozu, I., Mutlu, I., Sugozu, B., (2018). The effect of ulexite to the tribological properties of brake lining materials. Polymer Composites 39(1): 55-62, Doi: 10.1002/pc.23901.

[24] TSE 555., (1992). Highway Vehicles-Brake System-Brake Pads for Friction Brake. Ankara, Turkey.

[25] TSE 9076., (1991). Evaluation of Material Friction Properties with Small Experimental Parts-Brake Systems-Brake Pads.

[26] Hwang, H.J., Jung, S.L., Cho, K.H., Kim, Y.J., Jang, H., (2010). Tribological performance of brake friction materials containing carbon nanotubes. Wear 268(3-4): 519-25, Doi: 10.1016/J.WEAR.2009.09.003.

[27] Düzcükoğlu, H., Ekinci, Ş., Şahin, Ö.S., Avci, A., Ekrem, M., Ünaldi, M., (2015). Enhancement of Wear and Friction Characteristics of Epoxy Resin by Multiwalled Carbon Nanotube and Boron Nitride Nanoparticles. Tribology Transactions 58(4): 635-42, Doi: 10.1080/10402004.2014.998358.

[28] Cho, K.H., Jang, H., Hong, Y.S., Kim, S.J., Basch, R.H., Fash, J.W., (2008). The size effect of zircon particles on the friction characteristics of brake lining materials. Wear 264(3-4): 291-7, Doi: 10.1016/j. wear.2007.03.018. 